\title{
PREPARATION, PROPERTIES AND BIOLOGICAL ACTIVITY OF NATURAL AND SEMISYNTHETIC URETHANES OF MONENSIN
}

\author{
John W. Westley, Chao-min Liu, Ralph H. Evans, Jr., Lilian H. Sello, \\ Nelson Troupe and Theron Hermann \\ Department of Microbiology, Roche Research Center, Hoffmann-La Roche Inc. \\ Nutley, New Jersey 07110, U.S.A.
}

(Received for publication May 30, 1983)

\begin{abstract}
Conversion of the monovalent polyether antibiotic monensin into a series of urethane derivatives substituted at C-26 causes a ten-fold increase in the cation transporting properties of the antibiotic as well as making the resulting semisynthetic urethanes divalent ionophores. These changes must in part account for the enhanced antimicrobial activities of the urethanes. The most active derivatives are the phenylurethanes which are ten times more active in vitro against Gram-positive bacteria and unlike monensin are active against Candida albicans and Penicillium digitatum. Another novel activity exhibited by four of the urethanes was against Plasmodium berghei, the causative agent for malaria.
\end{abstract}

The isolation of the novel antibiotics X-14667A and X-14667B from Streptomyces cinnamonensis subsp. urethanefaciens was recently described ${ }^{1)}$. The confirmation of their structures as 2-phenethylurethanes of monensins $\mathrm{B}^{2)}$ and $\mathrm{A}^{3)}$ respectively by synthesis using 2-phenethylisocyanate suggested the synthesis of other monensin urethanes $(\mathbf{1} \sim \mathbf{1 4})$. In a similar study with the polyether antibiotic laidlomycin $^{4,5)}$, monoacylation has led to derivatives that display enhanced activity towards favorably altering rumen fermentation and preventing avian coccidiosis ${ }^{6}$. In the study described here, many of the semisynthetic monensin urethanes displayed greater activity than monensin (15) in a variety of in vitro and in vivo screens. The derivatives were active in vitro against Gram-positive bacteria, Penicillium digitatum, Candida albicans, the anaerobes Bacteroides fragilis and Clostridium histolyticum and C. septicum and Treponema hyodysenteriae. In addition several of the urethanes were active against Eimeria tenella in chicks and Plasmodium berghei in mice.

\section{Chemistry}

The preparation of antibiotics X-14667A (2) and X-14667B (3) from monensin B and A (15) has been described previously ${ }^{1)}$. The other urethanes were made in the same way using monensin $\mathrm{B}$, in the preparation of $\mathbf{4}$ and $\mathbf{5}$ and monensin A, to prepare the other urethanes. The reactions were carried out in benzene with an excess of the appropriate iso-cyanate and followed by silica gel TLC. At room temperature, the sodium salts were converted to their urethane analogs in one or two days whereas the free acid form of the antibiotics took about a week for complete reaction. Correct microanalyses were obtained for all fourteen analogs. The respective melting points of the sodium salts of the semisynthetic monensin urethanes are listed in Table 1.

Transport Properties

The U-tube system described by Ashton and STEInRauF ${ }^{\text {7) }}$ was employed to measure the monovalent and divalent cation transport properties of several monensin urethanes. A glass U-tube was filled with 
Table 1. Structure and melting points of the monensin urethanes.

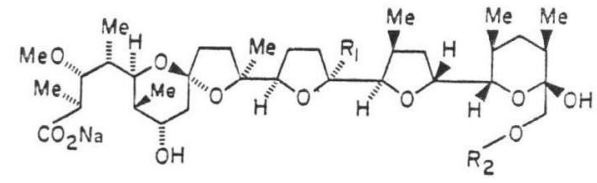

\begin{tabular}{|c|c|c|c|c|}
\hline & $\mathrm{R}_{1}$ & $\mathrm{R}_{2}$ & & $\mathrm{Mp}\left({ }^{\circ} \mathrm{C}\right)$ \\
\hline Alkyl & Et & & & $191 \sim 19 ?$ \\
\hline \multirow[t]{2}{*}{ Phen-2-alkyl } & $\mathrm{Me}$ & & 2 & 70 \\
\hline & Et & & 3 & 103 \\
\hline \multirow[t]{2}{*}{ Phen-1-alkyl } & $\mathrm{Me}$ & & 4 & $89 \sim 93$ \\
\hline & $\mathrm{Me}$ & & 5 & $116 \sim 120$ \\
\hline Cyclohexyl & Et & & 6 & $110 \sim 123$ \\
\hline \multirow{8}{*}{$\begin{array}{l}\text { 4-Substituted } \\
\text { phenyl }\end{array}$} & $\mathrm{Et}$ & & 7 & $210 \sim 213$ \\
\hline & Et & & 8 & $199 \sim 210$ \\
\hline & Et & & 9 & 220 \\
\hline & $\mathrm{Et}$ & & 10 & $199 \sim 223$ \\
\hline & Et & & 11 & $203 \sim 206$ \\
\hline & $\mathrm{Et}$ & & 12 & $201 \sim 203$ \\
\hline & $\mathrm{Et}$ & & 13 & $199 \sim 207$ \\
\hline & Et & 1) & 14 & $189 \sim 192$ \\
\hline Monensin & $\mathrm{Et}$ & H & 15 & \\
\hline
\end{tabular}

Table 2. Cation transport of monensin urethanes as measured by the U-tube system of AsHTon and SteinRauf.

\begin{tabular}{rlcc}
\hline & Monensin urethane & $\mathrm{Rb}^{+}(\%)$ & $\mathrm{Ca}^{2+}(\%)$ \\
\hline $\mathbf{1}$ & Methyl & 42 & 8 \\
$\mathbf{2}$ & 2-Phenethyl (X-14667A) & 31 & 2 \\
$\mathbf{3}$ & 2-Phenethyl (X-14667B) & 26 & 1 \\
$\mathbf{4}$ & (R)-1-Phenethyl & 28 & 5 \\
$\mathbf{5}$ & (S)-1-Phenethyl & 29 & 7 \\
$\mathbf{6}$ & Cyclohexyl & 25 & 4 \\
$\mathbf{7}$ & Phenoxyphenyl & 34 & 10 \\
$\mathbf{8}$ & Phenyl & 30 & 12 \\
$\mathbf{1 0}$ & Fluorophenyl & 40 & 14 \\
$\mathbf{1 1}$ & Iodophenyl & 31 & 14 \\
$\mathbf{1 3}$ & Chlorophenyl & 27 & 17 \\
$\mathbf{1 4}$ & Nitrophenyl & 35 & 19 \\
$\mathbf{1 5}$ & Monensin & 3 & 0 \\
\hline
\end{tabular}

Fig. 1. Proposed conformation of the sodium salt complex of the monensin urethanes.

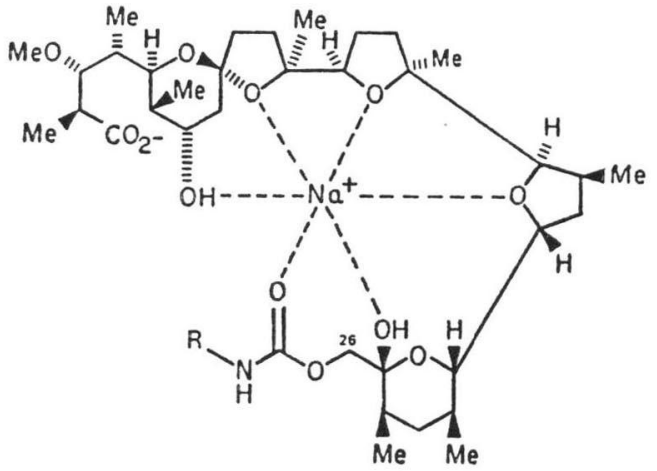

$5 \mathrm{ml}$ of a chloroform solution of the monensin urethane $\left(2 \times 10^{-4} \mathrm{M}\right)$. Two $\mathrm{ml}$ of an aqueous buffer (Tris-HCl, $20 \mathrm{~mm}, \mathrm{pH}$ 9.5) containing $1 \mathrm{~mm}\left[{ }^{45} \mathrm{Ca}\right]$ calcium chloride or $\left[{ }^{86} \mathrm{Rb}\right] \mathrm{rubidium}$ chloride was placed in one arm and an equal volume of the same buffer solution with unlabelled calcium or rubidium chloride in the other arm. The experiment was started by the addition of the respective labelled metal chloride and the chloroform phase separating the two aqueous phases was then gently stirred with a magnetic stirrer overnight. The percentage of labelled cation transported overnight was determined by counting $50 \mu \mathrm{l}$ samples taken from both aqueous phases with $10 \mathrm{ml}$ Aquasol (New England Nuclear, Boston, Mass.) in an Intertechnique liquid scintillation spectrometer. The results are summarized in Table 2.

From the results in Table 2, there is a clear indication that the urethane moiety attached to the hydroxyl group at C-26 of monensin causes a ten-fold enhancement in the monovalent cation-transporting properties of the parent antibiotic. In addition, the urethanes have the ability to transport divalent cations which monensin does not. These divalent properties are particularly marked in the monensin phenylurethanes (7 14).

A possible explanation for the enhanced cation transporting properties of these semisynthetic deriva- 
Table 3. In vitro minimum inhibitory concentrations (MIC) in $\mu \mathrm{g} / \mathrm{ml}$ of monensin urethanes as Gram-positive antibacterial agents.

\begin{tabular}{|c|c|c|c|c|c|c|c|c|c|c|c|}
\hline & $\begin{array}{l}\text { Monensin } \\
\text { urethane }\end{array}$ & $\begin{array}{c}\text { Staphylococcus } \\
\text { aureus } \\
\text { ATCC } 6538\end{array}$ & $\begin{array}{c}\text { Micrococcus } \\
\text { luteus } \\
\text { ATCC } 9341\end{array}$ & $\begin{array}{c}\text { Strepto- } \\
\text { coccus } \\
\text { faecium } \\
\text { ATCC } 8043\end{array}$ & $\begin{array}{c}\text { Bacillus } \\
\text { sp. E } \\
\text { ATCC } 27859\end{array}$ & $\begin{array}{c}\text { Bacillus } \\
\text { subtilis } \\
\text { NRRL } 583\end{array}$ & $\begin{array}{c}\text { Bacillus } \\
\text { megaterium } \\
\text { ATCC } 8011\end{array}$ & $\begin{array}{c}\text { Bacillus } \\
\text { sp. TA } \\
\text { ATCC } 27860\end{array}$ & $\begin{array}{c}\text { Myco- } \\
\text { bacterium } \\
\text { phlei } \\
\text { ATCC } 354\end{array}$ & $\begin{array}{l}\text { Streptomyces } \\
\text { cellulosae } \\
\text { ATCC } 3313\end{array}$ & $\begin{array}{l}\text { Paecilomyces } \\
\text { varioti } \\
\text { ATCC } 25820\end{array}$ \\
\hline 1 & Methyl & 25 & 25 & 1.6 & 6.3 & 1.6 & 6.3 & 12.5 & $>25$ & $>25$ & $>25$ \\
\hline 2 & $\begin{array}{l}\text { 2-Phenethyl } \\
(\mathrm{X}-14667 \mathrm{~A})\end{array}$ & 6.3 & 3.1 & 0.8 & 1.6 & 3.1 & 3.1 & 3.1 & 25 & 12.5 & $>25$ \\
\hline 3 & $\begin{array}{l}\text { 2-Phenethyl } \\
\text { (X-14667B) }\end{array}$ & 6.3 & 1.6 & 0.4 & 0.8 & 1.6 & 0.8 & 1.6 & 6.3 & 12.5 & 12.5 \\
\hline 4 & (R)-1-Phenethyl & 6.3 & 3.1 & 0.8 & 0.4 & 1.6 & 1.6 & 0.8 & 12.5 & 3.1 & 3.1 \\
\hline 5 & $(S)$-1-Phenethyl & 1.6 & 1.6 & 0.2 & 0.1 & 0.8 & 0.4 & 0.2 & 6.3 & 0.3 & 6.3 \\
\hline 6 & Cyclohexyl & 1.6 & 0.8 & 0.1 & 0.2 & 0.8 & 0.4 & 0.8 & 3.1 & 3.1 & 3.1 \\
\hline 7 & Phenoxyphenyl & 1.6 & 0.8 & 0.1 & 0.2 & 0.8 & 0.4 & 0.8 & 3.1 & 3.1 & 3.1 \\
\hline 8 & Phenyl & 0.8 & 0.4 & 0.4 & 0.1 & 1.6 & 0.6 & 0.8 & 1.6 & 0.8 & 3.1 \\
\hline 9 & Methylphenyl & 0.8 & 0.8 & 0.1 & 0.05 & 0.6 & 0.4 & 0.4 & 3.1 & 3.1 & 3.1 \\
\hline 10 & Fluorophenyl & 0.4 & 0.4 & 0.2 & 0.05 & 0.4 & 0.2 & 0.2 & 1.6 & 0.8 & 1.6 \\
\hline 11 & Iodophenyl & 0.6 & 0.2 & 0.1 & 0.02 & 0.4 & 0.2 & 0.2 & 1.6 & 0.4 & 1.6 \\
\hline 12 & Bromophenyl & 0.8 & 0.2 & 0.1 & 0.05 & 0.4 & 0.1 & 0.2 & 1.6 & 0.8 & 1.6 \\
\hline 13 & Chlorophenyl & 0.4 & 0.2 & 0.05 & 0.02 & 0.4 & 0.1 & 0.2 & 0.8 & 0.8 & 3.1 \\
\hline 14 & Nitrophenyl & 0.4 & 0.6 & 0.1 & 0.4 & 0.6 & 0.4 & 0.2 & 1.6 & 0.8 & 0.8 \\
\hline 15 & Monensin & 3.1 & 12.5 & 1.6 & 0.4 & 1.6 & 3.1 & 1.6 & 12.5 & 6.3 & $>25$ \\
\hline
\end{tabular}


Table 4. In vitro MIC's $(\mu \mathrm{g} / \mathrm{ml})$ of monensin urethanes against a mold, a yeast and a spirochete.

\begin{tabular}{rlccc}
\hline & Monensin urethanes & P. digitatum & C. albicans & T. hyodysenteriae \\
\hline $\mathbf{1}$ & Methyl & $>100$ & $>100$ & 50 \\
$\mathbf{2}$ & 2-Phenethyl (X-14667A) & $>100$ & 63 & 1.6 \\
$\mathbf{3}$ & 2-Phenethyl (X-14667B) & $>100$ & 25 & 0.4 \\
$\mathbf{4}$ & (R)-1-Phenethyl & $>100$ & 25 & 0.6 \\
$\mathbf{5}$ & (S)-1-Phenethyl & 50 & 25 & 0.4 \\
$\mathbf{6}$ & Cyclohexyl & 100 & 100 & 0.4 \\
$\mathbf{7}$ & Phenoxyphenyl & 50 & 6.3 & 0.08 \\
$\mathbf{8}$ & Phenyl & 25 & 25 & 0.08 \\
$\mathbf{9}$ & Methylphenyl & 12.5 & 6.3 & 0.08 \\
$\mathbf{1 0}$ & Fluorophenyl & 25 & 25 & 0.4 \\
$\mathbf{1 1}$ & Iodophenyl & 25 & 6.3 & 0.4 \\
$\mathbf{1 2}$ & Bromophenyl & 6.3 & 0.08 & 0.4 \\
$\mathbf{1 3}$ & Chlorophenyl & 25 & 25 & 0.16 \\
$\mathbf{1 4}$ & Nitrophenyl & $>100$ & $>100$ & \\
\hline
\end{tabular}

tives of monensin is the participation as a ligand of the urethane carbonyl oxygen (Fig. 1) as suggested earlier for antibiotics X-14667A and X-14667 $\mathrm{B}^{1)}$ and also invoked by CLARK et al. ${ }^{6)}$ to explain the anomalous ${ }^{13} \mathrm{C}$ NMR upfield shift of the C-26 carbon in the acyl esters of laidlomycin.

\section{Biological Properties}

The in vitro activity of the fourteen semisynthetic monensin urethanes against ten Gram-positive bacteria are compared with that of monensin in Table 3. In the case of monensin (15) only one bacteria, Bacillus sp. E was sensitive at MIC levels less than $1 \mu \mathrm{g} / \mathrm{ml}$. Apart from the monensin urethanes $\mathbf{1}$ and 2, all the semisynthetic derivatives were active against three or more bacteria at levels less than $1 \mu \mathrm{g} / \mathrm{ml}$ with increasing activity down the Table to the phenyl derivatives, 8 14 which were active against between seven and nine of the ten Gram-positive microorganisms tested at levels less than $1 \mu \mathrm{g} / \mathrm{ml}$. Against the most sensitive organism, Bacillus sp. E, five of the monensin phenylurethanes $(\mathbf{9} \sim 13)$ were active at levels less than $0.1 \mu \mathrm{g} / \mathrm{ml}$.

The monensin urethanes are also active in vitro against $P$. digitatum, $C$. albicans and $T$. hyodysenteriae (Table 4). Whereas monensin was inactive against both the mold, $P$. digitatum and the yeast, $C$. albicans, the cyclohexyl- (6) and phenylurethanes (7 14) were all active against both with monensin chlorophenylurethane (13) exhibiting activity against $C$. albicans at less than $0.1 \mu \mathrm{g} / \mathrm{ml}$. In addition, four of the phenylurethanes $(\mathbf{7}, \mathbf{9}, \mathbf{1 1}$ and $\mathbf{1 4})$ were compared with monensin (15) in vitro against three anaerobes, Bacteroides fragilis, $C$. histolyticum and $C$. septicum. The activities of the phenylurethanes were very similar to monensin against $B$. fragilis with MIC values between $25 \sim 100 \mu \mathrm{g} / \mathrm{ml}$ but were ten times more active against the two Clostridia with MIC values of $0.08 \sim 0.31 \mu \mathrm{g} / \mathrm{ml}$ compared to $3.1 \mu \mathrm{g} /$ $\mathrm{ml}$ for monensin. In Table 5, the in vivo activities of the monensin urethanes are summarized. The 24 hour $\mathrm{LD}_{50}$ values and the antimalarial activities vs. P. berghei were determined in the mouse and the coccidiostat activities vs. E. tenella were studied in chicks.

The toxicities (i.p. and p.o.) of the alkylurethanes of monensin $(\mathbf{1} \sim \mathbf{5})$ were all less than the parent antibiotic (15), but the phenylurethanes were very similar. One exception was the bromophenylurethane (12) which was approximately three times less toxic than monensin and in addition was active against $P$. berghei in mice at $16 \mathrm{mg} / \mathrm{kg}$ p.o. whereas monensin was inactive at five times that level. 
Table 5. Toxicity, antimalarial activity and coccidiostat activity of the monensin urethanes.

\begin{tabular}{|c|c|c|c|c|c|c|c|}
\hline \multirow{2}{*}{$\begin{array}{l}\text { Monensin } \\
\text { urethane }\end{array}$} & \multicolumn{2}{|c|}{$\begin{array}{c}\text { Mouse toxicity }(\mathrm{mg} / \mathrm{kg}) \\
24 \text { hours } \mathrm{LD}_{50}\end{array}$} & \multicolumn{2}{|c|}{$\begin{array}{c}\text { Antimalarial activity } v s . \\
P . \text { berghei }\end{array}$} & \multicolumn{3}{|c|}{$\begin{array}{l}\text { Coccidiostat activity vs. } \\
\text { E. tenella }\end{array}$} \\
\hline & i.p. & p.o. & p.o. in mice & $(\mathrm{mg} / \mathrm{kg})$ & p.o. in chicks & $(\mathrm{ppm})$ & $\mathrm{ADI}^{*}$ \\
\hline 1 & 77 & 190 & & & - & 120 & 2.8 \\
\hline 2 & 75 & 150 & + & 100 & & & \\
\hline 3 & 27 & 245 & & & - & 50 & 3.4 \\
\hline 4 & 77 & 250 & & & + & 70 & 1.1 \\
\hline 5 & 35 & 120 & - & 10 & - & 120 & 3.0 \\
\hline 6 & 14 & 140 & & & + & 120 & 0.8 \\
\hline 7 & 9 & 120 & - & 8 & - & 120 & 2.1 \\
\hline 8 & 22 & 77 & + & 4 & + & 120 & 0.5 \\
\hline 9 & 15 & 150 & - & 5 & + & 70 & 1.1 \\
\hline 10 & 24 & 45 & & & + & 70 & 0.8 \\
\hline 11 & 24 & 55 & - & 5 & + & 120 & 0.1 \\
\hline 12 & 50 & 140 & + & 16 & + & 70 & 0.5 \\
\hline 13 & 9 & 22 & + & 2 & + & 70 & 0.9 \\
\hline 14 & 12 & 45 & - & 5 & + & 70 & 0.5 \\
\hline Monensin (15) & 17 & 44 & - & 80 & + & 120 & 0.8 \\
\hline
\end{tabular}

* ADI is the average degree of infection and values of $<1.5$ indicate coccidiostat activity.

Phenylurethane (8) and chlorophenylurethane (13) derivatives were also active against $P$. berghei in mice, and at even lower levels than 12, namely 4 and $2 \mathrm{mg} / \mathrm{kg}$ p.o. respectively.

In regard to the coccidiostat activity vs. E. tenella in chicks, the most active derivatives were the fluoro-, bromo-, chloro- and nitrophenylurethanes $(10,12,13$ and 14) followed by the $(R)$-1-phenethyl, cyclohexyl-, phenyl-, methylphenyl- and iodophenylurethanes $(\mathbf{4}, \mathbf{6}, \mathbf{8}, 9$ and 11) which were about on a par with the parent antibiotic, monensin (15).

\section{Conclusions}

The conversion of monensin to its C-26 hydroxyl urethane derivatives has a profound effect on the cation transporting properties of the antibiotic. The ability of monensin to transport $\mathrm{Rb}^{+}$is increased ten-fold and in addition these semi-synthetic urethanes can cause the transport of $\mathrm{Ca}^{2+}$ which monensin cannot.

This change in physical chemical properties accounts in part for the enhanced biological activity of some of the urethanes described in this report. The most active derivatives are the phenylurethanes which are approximately one order of magnitude more active in vitro against Gram-positive bacteria than monensin. In addition, the phenylurethanes, unlike monensin, are active against $P$. digitatum and $C$. albicans. When tested in mice, three of the phenylurethanes are active against $P$. berghei at levels ranging from $2 \sim 16 \mathrm{mg} / \mathrm{kg}$ whereas monensin is inactive at $80 \mathrm{mg} / \mathrm{kg}$. Finally, the phenylurethanes exhibit enhanced coccidiostat activity against $E$. tenella in chicks.

\section{Acknowledgments}

We thank our colleagues at Hoffmann-La Roche, Dr. D. L. Pruess and Mr. E. LaSala for the antimicrobial tests and Drs. D. Siegel and E. SchiLdknecht for the Treponema hyodysenteria and coccidiostat results. The testing against Plasmodium berghei was carried out by our colleague in Basle, Dr. R. W. Richle. Pre!iminary results in this study were published by SCHILdKNeCHT, Siegel and Richle ${ }^{8)}$.

\section{References}

1) Westley, J. W.; R. H. Evans, Jr., L. H. Sello, N. Troupe, C-M. Liu \& P. A. Miller: Isolation of novel 
antibiotics X-14667A and X-14667B from Streptomyces cinnamonensis subsp. urethanofaciens and their characterization as 2-phenethylurethanes of monensin B and A. J. Antibiotics 34: 1248 1252, 1981

2) Gorman, M.; J. W. Chamberlin \& R. L. Hamill: Monensin, a new biologically active compound. V. Compounds related to monensin. Antimicrob. Agents Chemother. -1967: 363 368, 1968

3) Agtarap, A.; J. W. Chamberlin, M. Pinkerton \& L. Steinrauf: The structure of monensic acid, a new biologically active compound. J. Am. Chem. Soc. 89: 5737 5739, 1967

4) Kitame, F.; K. Utsushikawa, T. Kohama, T. Saito, M. Kikuchi \& N. Ishida: Laidlomycin, a new antimycoplasmal polyether antibiotic. J. Antibiotics 27: 884 888, 1974

5) KitAme, F. \& N. IshidA: The constitution of laidlomycin, a new antimycoplasmal antibiotic. J. Antibiotics 29: $759 \sim 761,1976$

6) Clark, R. D.; G. L. Hedden, A. F. Kluge, M. L. Maddox, H. R. Spires \& P. F. Long: Enhancement of the acitivity of the antibiotic laidlomycin by acylation and the ${ }^{13} \mathrm{C}-\mathrm{NMR}$ spectra of laidlomycin and its esters. J. Antibiotics 35: 1527 1537, 1982

7) Ashton, R. \& L. K. Steinrauf: Thermodynamic consideration of the ion transport antibiotics. J. Mol. Biol. 49: $547 \sim 556,1970$

8) Schildknecht, E. G.; D. Siegel \& R. W. Richle: Antiparasitic activity of natural and semisynthetic monensin urethanes. Chemotherapy 29: 145 152, 1983 